Measurement of the Impact of Driving Technique on Fuel Consumption: Preliminary Results. 1991. J. Nader. FERIC Technical Note TN-172. 6 pp.

Evaluation of Two Small Feller-bunchers. 1991. K. A. Raymond and G. Chabot. FERIC Technical Note TN-174. 8 pp.

Stand Conversion Using the Munger and Denis-Cimaf Brush Cutters. 1991. D. Cormier. FERIC Technical Note TN-167. 12 pp.

Evaluation of a Steyr KP40 Log Processor. 1991. Dennis Araki. FERIC Technical Note TN-169. 6 pp.

Evaluation of a Lim-mit LM2200 Log Processor. 1991. Dennis Araki. FERIC Technical Note TN-168. 8 pp.

Evaluation of a Denis DP550 Log Processor. 1991. Dennis Araki. FERIC Technical Note TN-178. 7 pp.

Performance and Utilization of the Finning RTD528 Rock Master Rock Drill. 1991. D. M. Bennett. FERIC Technical report TR-104. $16 \mathrm{pp}$.

Handbook on Portable Bandsaw-type Sawmills. 1992. Michael P. Folkema. FERIC Handbook HB-10. 65 pp.

\section{Cida Publications}

Sustaining our Forests. 1991. Bilingual format. An eight-page summary of CIDA's Forestry Program which includes brief descriptions of CIDA projects in Honduras, Kenya, Zaire, China, Peru, Malawi, Asean Countries and Brazil.

Forestry Issues. CIDA and International Forestry. 1992. 4 page fact sheet.

Forestry Profiles. Biological Pest Control in Eastern and Southern Africa. 1991. 3 page fact sheet.

Principles and Practices of New Forestry. A Guide for British Columbians. Doug Hopwood. 1991. British Columbia Ministry of Forests. Report Commissioned by the old-growth strategy working group. $95 \mathrm{pp}$. Land Managers Rept. No. 71. 95 pp.

The term "New Forestry" denotes an approach to forestry developed over the past decade in the U.S. Pacific Northwest, west of the Cascades, in response to a broadening of forest management objectives and an improved knowledge of forest ecosystems.

New Forestry has not been formally defined, but has been summarized as "an attempt to define forest management with timber production as a by-product of its primary function: sustaining biological diversity and maintaining long-term ecosystem health.",
The social background to New Forestry includes an increased public concern with environmental issues such as loss of biodiversity in managed forests. At the same time, economic pressure to harvest oldgrowth timber has remained strong. These conflicting forces have led forest managers to seek better methods of integrating biodiversity and ecological concerns with timber management.

The scientific background includes an increased understanding of:

- structure/function/composition relationships in old-growth forests, and the importance of specific structural features such as large trees, standing dead trees (snags), large down logs, and the heterogeneous canopy structure;

- the extent to which such structures tend to persist through natural disturbance events such as wildfire or windstorms, providing "biological legacies" for the subsequent stand;

- the habitat value of early and late seral stages of forest, which are reduced or eliminated through intensive management; and

- the importance of large-scale and longterm effects of forest management. Other research has focused on long-term site productivity and ecological resilience.

Practices that have been proposed or adopted at the stand level include:
1. logging methods to retain standing green trees, snags, and down logs;

2. establishment of mixed species stands;

3. stand treatments to encourage development of large, widely spaced trees; and

4. other practices to enhance the diversity of managed stands or promote development of old-growth characteristics.

Practices at the landscape level have focused on minimizing forest fragmentation, providing habitat reserves and dispersal corridors within the industrial forest landscape, and integrating the long-term and large-scale effects of timber operations with ecological concerns.

In an evaluation of the applicability of New Forestry practices to British Columbia, the most important issue that predominates is that of forest management goals. New Forestry is based on the premise that conventional forestry practices sacrifice many of the ecological elements of the forest, and it seeks to conserve them by developing alternative practices. We cannot judge how applicable those practices are to the province until we decide how highly we value those ecological elements.

The ecological applicability of New Forestry varies. Some practices may only be suitable to a restricted portion of British Columbia forests, while others could be applied widely. However, forest management prescriptions must be specific to regional, site, and stand conditions.

\title{
Book Review/Revue de livre
}

L'Arbre: Biologie et Developpement. C. Edelin (Ed.), Actes du $2^{\text {emc }}$ Colloque international sur l'Arbre, Montpellier septembre 1990, Naturalia Monspeliensia, Institut de Botanique, Université Montpellier II, 163 rue Auguste Broussonet, 34000 Montpellier, France, 673 p., 1991, ISSN 0-373-518-X.

This attractive, large-format (almost $21 \times$ $30 \mathrm{~cm}$ ) volume constitutes the proceedings of a colloquium attended by some 250 scientists of diverse biological disciplines from 23 countries at the venerable Montpellier University in the south of France in September 1990. This was the Second International Colloquium of the Tree.

During the week-long meeting, many different but interrelated aspects of the biology and development of trees were explored. Papers (22 in French, 15 in English) are grouped into presentations on: the fossil tree, the architecture of tree root systems, the architecture of tree crowns, growth rhythms, morphogenesis, allocation of resources, and pathology. Two-page accounts of the more than 60 posters contribute further valuable dimensions to the proceedings.
In these days of specialization, the concept of deliberately seeking to embrace a great broadness of subject matter within the ambit of one colloquium might be viewed with reservation by some. But, in the event, this particular mixing of specialists produces an excitement in the mind. Eyes that have been narrowly focused within individual fields of endeavor are refreshed by vistas long neglected or even, perhaps, unsuspected. Within the range of subject matter indicated above, a given reader will probably turn initially to topics in his or her own field, but, for many, the temptation to browse more widely will be irresistible. This was precisely the intention of the organizers, who are to be congratulated for so successfully devising this format.

The proceedings succeed very well in capturing the essence of the meeting. Editing has been excellent, and the generous, uncluttered format, together with illustrations large enough to reveal their meaning, have produced a volume that is exceptionally clear and a pleasure to read. 